\title{
Determinants Of Intellectual Capital Disclosure On University's Official Website
}

\author{
Nadya Novianty \\ \{naaddyya@gmail.com\} \\ Affiliation, Sari Mulia University
}

\begin{abstract}
This study aims to find the determinants that can influence intellectual capital disclosure on the university's official website. This research is a literature study by searching for reference theory that is relevant to the case or problem found and using descriptive analysis method as a data analysis method. The type of data used in this study is secondary data that is data obtained from journals, books, documentation, and the internet. The results of this study indicate that the profit center, college ownership/status, university size, complexity, international programs, and accreditation status can significantly influence intellectual capital disclosure on the university's official website.
\end{abstract}

Keyword: intellectual capital, intellectual capital disclosure, university's official website

\section{Introduction}

In the economic world, intangible assets and intellectual capital (IC) have become a major issue, not only for academics but also for governments, regulators, companies, investors and other stakeholders. Now intellectual capital is starting to get attention from community organizations, research centers and universities [1]. Higher education becomes the object of great attention in the development of intellectual capital outside the conventional/profitoriented pathway. This is because the main objective of tertiary institutions is to produce and disseminate knowledge and develop human resources [2]. Furthermore, in community organizations and tertiary institutions, human resources are the main factor in IC disclosure, this is why universities are important to disclose intellectual capital because to enhance development and competition with tertiary institutions. the other valuable asset is human resources [3]. The preparation of IC reports in tertiary institutions is more difficult than the preparation of IC reports in the industry because tertiary institutions have different goals and those goals will determine their performance.

Based on the rapid development of technology, an institution's official website becomes very important, because of the official website as an electronic medium for communicating and giving the business world the ability to provide business, financial and other information for external users in periods ranging from annual, theoretically quarterly and real-time. The use of the Web for information reporting purposes is generally referred to as online reporting [4]. The use of the web for information dissemination and publication is also carried out by universities, the use of the internet for universities is greatly appreciated by organizations that aim to improve the quality of universities in the world to assess and reward web rankings, such as Webometrics, Four International Colleges \& Universities (4ICU ), and Qs-Star. 
The results of Bezhani (2010), state that the practice of intellectual capital disclosure in the annual reports of tertiary institutions in the UK is still low [5]. In this study, Bezhani provided an online questionnaire adopted from IC frameworks implemented by universities in Austria. The results of research conducted by Puspitahati et.,al (2011) in three tertiary institutions in Indonesia based on world organization ranking webometrics, showed that IC disclosure at three state universities in Indonesia was still low, none of the tertiary institutions in Indonesia revealed the items in full. This can be proven by the total component disclosure at the university which has not reached the maximum score, the highest percentage of disclosure has not reached $50 \%$ of the number of university IC items. Besides, each component has not shown equity because many components have not been disclosed by three state universities in Indonesia [6].

Ulum and Pratiwi (2012) examined the disclosure of IC on the websites of Indonesian universities per Qs-Star, using components using the university IC components, which consider higher education standards in Indonesia as regulated by the National Higher Education Accreditation Board (BAN-PT). The results of the research the highest number of IC disclosures were Airlangga University which revealed 33 items from three categories while the lowest was the Bandung National Institute of Technology which only revealed 12 items, based on the results of the study it could be said that the total IC disclosure at Qs-Star winning universities in Indonesia had not been fulfilled [7]. Pahlevi et.,al (2016) examined the disclosure of IC at Muhammadiyah Universities by using analyst content on the website they own. The results of the study stated that of the 10 Muhammadiyah University websites analyzed, none revealed a complete IC, it showed that the disclosure of IC on the website was still low [3]. Based on the phenomenon of intellectual capital disclosure that is still low and the development of tertiary institutions, it attracts the attention of the writer to research the determinants that influence IC disclosure on the official website of the university.

\section{Literature Review}

Intellectual capital is a group of knowledge assets that are organizational attributes and contribute significantly to increasing the competitive position by adding value to interested parties. Furthermore, IC define as the hidden value of the business. The term hidden here is used for two related things. First, IC especially intellectual assets or knowledge assets are not generally visible like traditional assets and second, such assets are usually not seen in financial statements [8]. Intellectual Capital information reporting for universities is a tool that wraps up the entire process of knowledge production within the University. Disclosure of Intellectual Capital at the University depends on the task of allocating budgets, their explicit way of defining organizational goals and economic strategies more broadly and extensively with other organizations' research comparisons. Report preparation According to Bontis in his journal entitled "A Review of The Models Used to Measure Intellectual Capital" states that Intellectual Capital consists of three main elements [9]: 


\subsection{Human Capital}

Human capital is the lifeblood of intellectual capital. Here is the source of innovation and improvement, but it is a component that is difficult to measure. Human capital is also a very useful source of knowledge, skills, and competencies in an organization. Characteristics of human capital in universities consist of: Number of full time professors, Number and type of research, Number of permanent lecturers, Number of non-permanent lecturers (outstanding lecturers, contract lecturers, expert lecturers), Lecturer achievements (awards, grants, program funding), qualifications (number of positions) academic lecturers, academic lecturer competencies (number of S1, S2, S3 lecturer education levels), number of non-academic staff (librarians, laboratory assistants, technicians).

\subsection{Structural Capital}

Structural capital is the ability of an organization to fulfill organizational routine processes and structures that support employee efforts to produce optimal intellectual performance and overall business performance. The characteristics of structural capital in universities are divided into four parts, namely structural capital, organizational culture, learning and teaching systems, and final assignment guidance systems.

\subsection{Relational Capital}

Relational Capital is a harmonious relationship/association network that an organization has with its partners. The characteristics of relational capital in universities consist of four parts, namely research and publication, knowledge transfer to the public, student relations, and alumni relations

\section{Methodology}

This research is literature study research by finding reference theories that are relevant to the case or problem and using descriptive analysis method as a data analysis. The type of data used in this study is secondary data that obtained from journals, books, documentation, and the internet. 


\section{Result}

Table 1. Summary of Intellectual Capital Disclosure

\begin{tabular}{|c|c|c|}
\hline Author & Determinants & Result \\
\hline \multirow{3}{*}{$\begin{array}{l}\text { Ulum dan Novianty } \\
\text { (2012) [1] }\end{array}$} & 1. age & no significant \\
\hline & 2. profit center & significant \\
\hline & 3. ownership status & significant \\
\hline \multirow{3}{*}{ Fathony et.,al (2016) [10] } & 1. age & no significant \\
\hline & 2. size & significant \\
\hline & 3. accreditation status & no significant \\
\hline \multirow{4}{*}{ Aulia et..al (2019) [11] } & 1. size & significant \\
\hline & 2. complexity & significant \\
\hline & $\begin{array}{l}\text { 3. international } \\
\text { programs }\end{array}$ & significant \\
\hline & 4. accreditation status & significant \\
\hline
\end{tabular}

Based on table 1, the results show that the determinants that can significantly influence intellectual capital disclosure are profit center, ownership status/college status, university size, complexity, international programs, and accreditation status.

University's profit center can be defined as an activity that can generate income outside of the tuition fees paid by students. According to Ulum and Novianty (2012) what supports a positive relationship between the level of voluntary disclosure and profitability is the existence of high financial resources to present other disclosures other than those required (voluntary) [1]. The profit center management indicates that the university has an independent funding source that will increase the wealth of the college. According to Ulum and Novianty (2012), the richer an organization is, the more the organization will inform the public of its assets and reveal voluntary matters.

The status of ownership/status of a tertiary institution can be defined as whether the tertiary institution is a state tertiary institution (PTN) or a private tertiary institution (PTS). The status of tertiary institutions, both public and private, has different ownership, state universities are owned by the government and universities are owned by foundations / nongovernmental organizations, this will certainly affect voluntary disclosures because they have different reasons and interests.

The size of a university can be measured by how many students it has. The greater the number of students, the greater the size of the university and the greater the responsibility of the university to the community, the more voluntary disclosure is shown to the public on the website that is owned. According to Gallego et al. (2011) university complexity refers to the number of offices, study programs, and faculties, can influence the design and display of its website to facilitate information retrieval and larger universities (in terms of the number of faculties) tend to reveal more information about their sites than smaller ones [12]. Furthermore, Rossi et al. (2018) state that complexity positively influences the level of disclosure of web-based universities, because the amount of information to disseminate increases in proportion to the number of departments involving the disclosure of IC contents. [13] 
International programs are defined as cooperation between nations carried out by universities. According to Aulia et., al (2019) international cooperation will not be well established if among the universities do not have a parallel quality [11]. International programs are also an indicator of the assessment of top universities. Therefore, the more international programs a university has, the university has more responsibility or accountability to stakeholders through the better disclosure of intellectual capital information. The existence of international college programs must disclose more information to recruit more foreign students, the website will be the main source of knowledge about university activities, services, and financial conditions, this can create a competitive advantage in an increasingly competitive market for each tertiary institution. An international program can also reveal the courses offered, facilities available, faculties and other issues that can be useful to make people or prospective students and stakeholders determine good quality.

Accreditation status is obtained from the Higher Education National Accreditation Board (BAN-PT). Higher education that has been accredited, can become a mediation of information to many parties such as prospective students, parents, the labor market and the government, and can be of more value to the college itself. Higher education that has good quality can be seen from the status of accreditation because it all depends on the quality of human resources owned by each tertiary institution. The better the status of accreditation, the better the quality in information management should be in the form of mandatory or voluntary disclosure as well as adding IC scores to tertiary institutions.

\section{Conclusion}

The results of this that profit center, ownership status/college status, university size, complexity, international programs, and accreditation status can significantly influence intellectual capital disclosure. 


\section{References}

[1] Ulum, I., dan N. Novianty.: Analisis Faktor-Faktor Yang Mempengaruhi Pengungkapan Intellectual Capital Pada Official Website Perguruan Tinggi Indonesia. Simposium Nasional Akuntansi XV. Banjarmasin. (2012)

[2] Canibano, L., dan M. P. Sanchez.: Intangibles in Universities: current challenges for measuring and reporting. Journal of Human Resource costing and Accounting, Vol. 13, No. 2, hlm: 93-104. (2009)

[3] Pahlevi,R.,Ulum,I.,Harventy,G.:Analisis Praktik Pengungkapan Intellectual Capital oleh Perguruan Tinggi Muhammadiyah. $2^{\text {nd }}$ ICAF UMY.Yogyakarta. (2016)

[4] Vasal V.K ,and P. Srivastava.: Internet, XBRL, and online Bussines Reporting Challenges and Opportunities.(2003)

[5] Benzhani, ivoni.:Intellectual Capital Reporting at UK Universities. Jurnal of intellectual capital.http//www.emeraldinsight.com/1469-1930.htm.(2010)

[6] Puspitahati, A., I. Ulum., dan A. Prasetyo.: Kajian Penelitian Aktual, Bidang Ekonomi dan Bisnis Dalam Rangka Meningkatkan Kinerja Organisasi, Perusahaan, Pemberdayaan Masyarakat dan Perekonomian Nasional. Proseding; Seminar Nasional Call for Paper 2011.9 Februari. Malang. (2011)

[7] Ulum, I., dan R. Y. Pratiwi. 2012.:Analisis Praktik Pengungkapan Intellectual Capital Pada Website Universitas Peraih QS-Star 2011. Artikel dipresentasikan pada Simposium Nasional Akuntansi \& Bisnis, di Bandung.(2012)

[8] Edvinsson, L. and Malone, M. S.: Intellectual Capital, New York: HarperCollins Publishing, Inc. 1999.

[9] Bontis, N. : Assessing knowledge assets: a review of he models used to measure intellectual capital. International Journal Of Technology Management. Vol. 3 No. 1. Pp.41-60.(2001)

[10] Fathony,M.M.,Ulum.I.:University’s Characteristic, Accreditation Status, and Intellectual Capital Disclosure: Evidance From Indonesia. Int. J.Eco.Res. V9 i6, 23-26. (2018)

[11] Aulia, Desti.:Pengaruh Ukuran, Kompleksitas, Program Internasional, dan Status Akreditasi Terhadap Pengungkapan Intellectual Capital Pada Universitas Muhammdiyah di Indonesia.Skripsi.Tidak diterbitkan. Fakultas Ekonomi dan Bisnis. Universitas Muhammadiyah Malang. (2019)

[12] Gallego-Álvarez, I., Rodríguez-Domínguez, L., \& García-Sánchez, I. M.: Information disclosed online by Spanish universities: Content and explanatory factors. Online Information Review, 35(3), 360-385. (2011)

[13] Rossi, Nicolo, \& Polcini.:New trends in intellectual capital reporting: Exploring online intellectual capital disclosure in Italian universities. Journal of Intellectual Capital, 19(4), 814-835. (2018) 